O Open Access Full Text Article

\title{
Arsenic Disulfide Promoted Hypomethylation by Increasing DNA Methyltransferases Expression in Myelodysplastic Syndrome
}

This article was published in the following Dove Press journal:

Drug Design, Development and Therapy

\author{
Qing-Bing Zhou (D) \\ Zheng-Tang Liu' \\ Hong-Zhi Wang ${ }^{2}$ \\ Xiao-Qing Guo ${ }^{2}$ \\ Yong-Gang $\mathrm{Xu}^{2}$ \\ Xiao-Mei Hu${ }^{2}$ \\ 'China Academy of Chinese Medical \\ Sciences, Institute of Geriatric Medicine, \\ Xiyuan Hospital, Beijing, People's \\ Republic of China; ${ }^{2}$ Department of \\ Hematology, Xiyuan Hospital, China \\ Academy of Chinese Medical Sciences, \\ Beijing, People's Republic of China
}

Correspondence: Xiao-Mei Hu Department of Hematology, Xiyuan Hospital, China Academy of Chinese Medical Sciences, Xiyuan Playground No. I, Haidian District, Beijing 10009I, People's Republic of China Tel +86I86I0350593

Email huxiaomei_2@163.com
Background: Previous studies have shown that DNA methylation plays a significant role in myelodysplastic syndrome (MDS). In addition to hypermethylation, aberrant hypomethylation can result in the transcriptional activation of oncogenes in cancer, including MDS. Therefore, drugs targeting DNA hypomethylation are needed for the treatment of MDS. This study aimed to investigate whether $\mathrm{As}_{2} \mathrm{~S}_{2}$ promoted hypomethylation by increasing DNA methyltransferases (DNMTs) expression in MDS.

Patients and Methods: Ten bone marrow samples from MDS patients and 3 healthy donors were obtained for the examination of the DNA methylation with a Human Methylation 850K BeadChip. The mRNA expressions for the DNMTs in the ten MDS patients and 3 controls were compared by Q-PCR. Then, the MDS cell line SKM-1 was treated with $\mathrm{As}_{2} \mathrm{~S}_{2}$. After 2 days of treatment, Human Methylation $850 \mathrm{~K}$ BeadChip was applied to analyze the changes of gene methylation status in the cells. Q-PCR and Western blot were taken to test the changes of mRNA and protein expressions for DNMTs in SKM-1 cells after treatment.

Results: Five hundred ninety-two abnormally hypomethylated genes were found in MDS patients compared to those in controls by Human Methylation 850K. The mRNA expressions of DNMTs (DNMT1, DNMT3a and DNMT3b) in MDS patients were significantly lower than those in healthy individuals. The IC50 value of $\mathrm{As}_{2} \mathrm{~S}_{2}$ for SKM-1 cells was $4.97 \mu \mathrm{mol} / \mathrm{L}$. Treatment with $\mathrm{As}_{2} \mathrm{~S}_{2}$ at $2 \mu \mathrm{moL} / \mathrm{L}$ resulted in significant alterations in the methylation levels at 1718 sites in SKM-1 cells compared to those in the controls. Hypermethylation was observed in 1625 sites $(94.58 \%)$, corresponding to 975 genes, compared to those in the controls. Finally, the expression levels of DNMTs (DNMT1, DNMT3a, and DNMT3b) significantly increased in SKM-1 cells treated with $\mathrm{As}_{2} \mathrm{~S}_{2}$ at $2 \mu \mathrm{moL} / \mathrm{L}$ and $4 \mu \mathrm{moL} / \mathrm{L}$.

Conclusion: These data show a potential clinical application of $\mathrm{As}_{2} \mathrm{~S}_{2}$ as an innovative hypermethylation agent in MDS.

Keywords: arsenic disulfide, myelodysplastic syndrome, hypermethylation, SKM-1 cell line

\section{Plain Language Summary}

DNA aberrant hypomethylation plays an important role in the development of myelodysplastic syndrome (MDS). For example, Papaggeli PC demonstrated that the oncogenes c-myc and c-fos were often aberrantly hypomethylated in MDS. The aberrant hypomethylation of SALL4 was often observed in patients with higher risk of MDS. De-Hong Wua reported that MDS patients with the hypomethylation of let-7a-3 is associated with poor prognosis. So targeting the aberrant hypomethylation could be very important for the MDS treatment. However, there is no such drug that can promote the aberrant hypomethylation at present. In this study, 592 hypomethylated genes were found in MDS patients when compared with 
those in healthy people and the expression of DNA methyltransferases (DNMTs) was lower than those in healthy donors. More important, data indicated that arsenic disulfide $\left(\mathrm{As}_{2} \mathrm{~S}_{2}\right)$ could promote the hypomethylation in MDS cell line through increasing the expression of DNMTs. Our data show a potential clinical application of $\mathrm{As}_{2} \mathrm{~S}_{2}$ as an innovative hypermethylation agent in the treatment of MDS.

\section{Introduction}

Abnormal DNA methylation plays an important role in nearly all kinds of cancer. ${ }^{1,2}$ Aberrant hypomethylation and hypermethylation events are common in acute myeloid leukaemia (AML) and myelodysplastic syndrome (MDS). ${ }^{2-6}$ DNA hypermethylation has caused great interest because of its direct impact on tumour suppressor genes. Hypermethylation in the promoter of cancerrelated genes causes the reversible silencing of tumor suppressor genes. ${ }^{7}$ The targeted treatment of DNA hypermethylation has become a research goal, and the approval of azacitidine (AZA) and decitabine (DAC) for treatment of MDS represented the most significant progress in the last dozen years. ${ }^{8}$ However, studies have shown that many patients do not acquire response after demethylation therapy and other patients eventually relapsed who initially respond to DAC or AZA treatment. ${ }^{9}$ Thus, there is an obvious need to develop novel drugs for DNA methylation-targeted therapy.

Cancer progression is also associated with DNA hypomethylation, which also affects the expression of cancerrelated genes and drives the leukaemogenic process in MDS and AML. ${ }^{10}$ DNA hypomethylation is involved in the development of cancer because it leads to transcriptional activation of oncogenes. Papaggeli PC demonstrated that proto-oncogenes c-myc and c-fos were often aberrantly hypomethylated in MDS and AML. ${ }^{11} \mathrm{~A}$ study showed that the frequency of SALL4 hypomethylation significantly increased in patients with a higher risk of MDS. ${ }^{12}$ De-Hong Wua reported that in MDS patients, the hypomethylation of let-7a-3 is associated with poor prognosis. $^{13}$ Therefore, drugs targeting DNA hypomethylation are needed for the treatment of patients with MDS. However, there are no such drugs that can improve the aberrant hypomethylation in MDS.

In the present study, we found that many abnormally hypomethylated genes existed in MDS patients and that $\mathrm{As}_{2} \mathrm{~S}_{2}$ could upregulate the hypomethylation by increasing DNMTs expression in MDS cell line SKM-1.

\section{Patients and Methods}

\section{Patients and Samples}

A total of ten MDS patients were included for the methylation checking in the study. Table S1 shows the details regarding the MDS patients, who were diagnosed according to $2008 \mathrm{WHO}$ classification system. ${ }^{14}$ Bone marrow cells were obtained from MDS patients and 3 healthy donors. The healthy donors were used as controls for the checking (Table S2). All patients and healthy individuals provided informed consent, and the study was approved by the medical ethics committee of Xiyuan hospital (2018XLA005-2). The sample collection was conducted in accordance with declaration of Helsinki.

\section{Reagents and Cell Line}

$\mathrm{As}_{2} \mathrm{~S}_{2}$ (Sigma-Aldrich, Missouri, America) was dissolved in 1 $\mathrm{M} \mathrm{NaOH}$, and the $\mathrm{PH}$ value was adjusted to 7.35-7.45 with the use of HCL to make a stock solution. The MDS cell line SKM$1,{ }^{15}$ established from a patient with myelomonocytic leukaemia derived from myelodysplastic syndrome, was provided by Professor Su-ning Chen in the First Affiliated Hospital of Soochow University, Institute of Hematology of Jiangsu Province. The use of the gifted cell line was approved by the medical ethics committee of Soochow University. SKM-1 cells were cultured in RPMI-1640 supplemented with 10\% inactivated FBS (Gibco, California, USA).

\section{WST-8 Cell Viability Assay and Drug}

\section{Treatment}

Cell proliferation was measured using water-soluble WST-8 during a spectrophotometric assay (EnoGene, Nanjing, China). The cells were seeded at a density of $1 \times 10^{4}$ cells per well in flatbottomed 96 well plates. Serially diluted concentrations of $\mathrm{As}_{2} \mathrm{~S}_{2}$ were added to the wells. After $48 \mathrm{~h}$ of incubation, $10 \mu \mathrm{L}$ of WST- 8 reagent was added. The absorbance of the samples was measured using a microplate reader (BioTek, Vermont, America) at $450 \mathrm{~nm}$. The experiments were repeated twice. The $50 \%$ inhibitory concentration value (IC50) was calculated and the drug treatment concentrations were determined. In this study, SKM-1 cells were seeded in 6 well plates and treated with $\mathrm{As}_{2} \mathrm{~S}_{2}$ at $0 \mu \mathrm{moL} / \mathrm{L}, 1$ $\mu \mathrm{moL} / \mathrm{L}$, and $2 \mu \mathrm{moL} / \mathrm{L}$ for $48 \mathrm{~h}$, respectively; then, the cells were collected for subsequent experiments.

\section{Human Methylation 850K BeadChip Analysis}

Genomic DNA was extracted from bone marrows and SKM-1 cells using a NucleoSpin Tissue kit (Macherey-Nagel, Germany). Illumina Inc. provided the $850 \mathrm{~K}$ DNA methylation array, which is 
a highly reproducible device for DNA methylation detection. ${ }^{16}$ In our study, the methylation status in DNA samples were analysed by the Illumina Human Methylation $850 \mathrm{~K}$ array. Briefly, an EZ DNA methylation kit (Zymo Research, CA, USA) was used and the bisulfite conversion of $1 \mu \mathrm{g}$ DNA of each sample was performed. Then, bisulfite-treated DNA was hybridized on Methylation 850 BeadChip, following the Infinium HD Methylation protocol. SQ fluorescent scanner was used. Fully methylated DNA produced a ratio that approaches 1 , whereas if methylation was completely absent, then the ratio would approach 0 . The differentially methylated genes were analysed by GO analysis, which is an important bioinformatics tool for screening related functions. ${ }^{17,18}$

\section{Reverse Transcription PCR}

Cells from bone marrow and SKM-1 were collected and total RNA was extracted with the use of an Ultrapure RNA Kit (CW bio, Beijing, China). Then, reverse transcription was performed and fluorogenic quantitative PCR was performed in $25 \mu \mathrm{L}$ reaction volumes containing Ultra SYBR Mixture, forward and reverse primers (Sangon, Shanghai, China), a cDNA template and water. GAPDH was chosen as the housekeeping gene. All of the primers used are listed in Table S3. The amplification conditions were $95^{\circ} \mathrm{C}$ for $10 \mathrm{~min}$, followed by 45 cycles of $95^{\circ} \mathrm{C}$ for $15 \mathrm{~s}$ and $60^{\circ} \mathrm{C}$ for 1 min using a Line Gene 9600 Plus (Bioer Technology, Hangzhou, China). PCR products were confirmed by melting curve analysis. Relative changes for the target genes were determined after normalization to the expression of GAPDH.

\section{Western Blotting}

Protein was extracted with the use of Protein Extraction Kit (Gene pool, China) according to manufacturers' instructions. Then, the protein concentration was determined by a BCA protein assay. Next, protein samples were loaded to SDS-PAGE and transferred to a PVDF membrane. After blocking in 5.0\% non-fat milk for $1 \mathrm{~h}$ at room temperature, the specific primary antibodies were incubated with the PVDF membrane at $4^{\circ} \mathrm{C}$ overnight (Abcam, Cambridge, USA). Then, secondary antibodies were added, enhanced chemiluminescence (ECL) reagents (Thermo, USA) were used to detect the antigenantibody binding. Quantity One v.4.6.2 was utilized for the quantification of the total gray area of each protein band.

\section{Statistical Analysis}

Statistical significance of the difference between the values of the methylation status for different samples that were measured with Human Methylation $850 \mathrm{~K}$ was assessed using Bayesian and linear regression. $\mathrm{CpG}$ sites with both p-values $<0.05$ and a minimum change of \pm 0.1 in the $\beta$-values were considered significant. The expressions of mRNA and proteins among different groups were analysed using one-way ANOVA with Dunnett's test. A value of $P<0.05$ was considered significant.

\section{Results \\ Many Abnormally Hypomethylated Genes Existed in MDS Patients}

No differences were observed in gender and age between the MDS patients and healthy donors $(P=0.729$ and 0.865$)$. Then, we analysed data from $>853,000 \mathrm{CpG}$ sites with an Illumina Methylation EPIC BeadChip in BM samples from ten MDS patients and 3 healthy individuals. The Bayesian and linear regression analysis showed there were 2421 sites that were significantly differentially methylated in MDS patients compared to those in healthy individuals. Among these sites, 1118 were hypomethylated and 1303 were hypermethylated in MDS patients, which corresponded to 592 hypomethylated and 654 hypermethylated genes, respectively, compared to those in healthy individuals (data not shown). Heatmap and Volcano plot between ten MDS patients and 3 healthy individuals are shown in Figure $1 \mathrm{~A}$ and B. According to Go analysis, these aberrant hypomethylated genes took part in many cancer-related functions and pathways, including the apoptotic process, cell proliferation, the Wnt receptor signalling pathway, and the glutamate receptor signalling pathway (Figure 1C).

\section{The Lower Expressions of DNMTs in MDS Patients}

We analyzed mRNA expressions of DNMTs (DNMT1, DNMT3a and DNMT3b) in the ten untreated MDS patients by real-time fluorescent quantitative PCR. The expressions of these 3 genes in MDS patients were significantly lower than those in healthy donors ( $p$-value $<0.05)$ (Figure 2).

\section{Effects of $\mathrm{As}_{2} \mathrm{~S}_{2}$ on the Proliferation of SKM-I Cells}

The chemical structure of $\mathrm{As}_{2} \mathrm{~S}_{2}$ is shown in Figure 3A. The inhibition of proliferation was observed in SKM-1 cell line after treatment with $\mathrm{As}_{2} \mathrm{~S}_{2}$ at concentrations ranging from 0 to $16 \mu \mathrm{M}$ for $48 \mathrm{~h}$ in a dose-dependent manner compared to that in controls (Figure 3B). The IC50 of $\mathrm{As}_{2} \mathrm{~S}_{2}$ for SKM-1 cells was 4.97 $\mu \mathrm{mol} / \mathrm{L}$. 


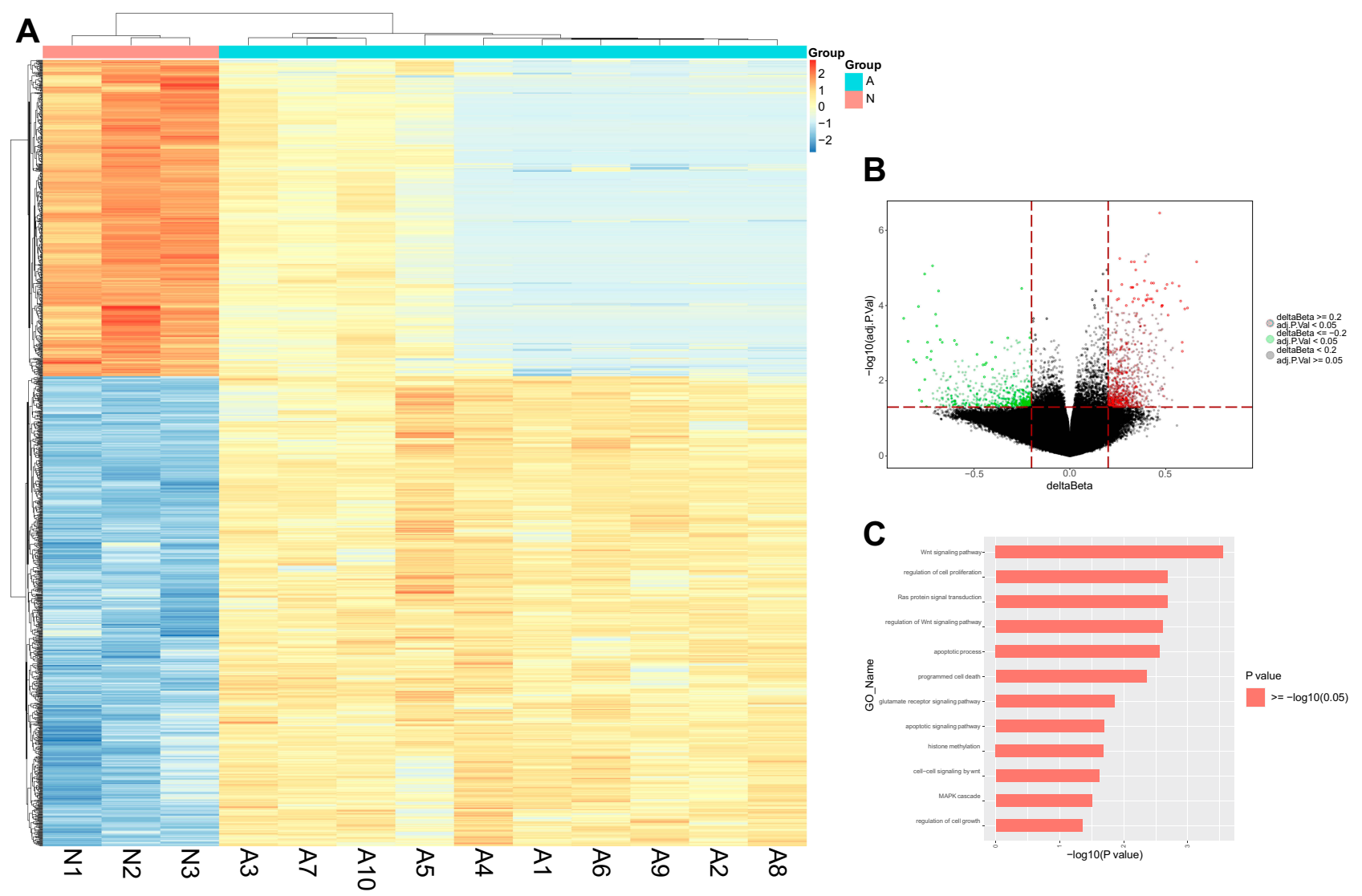

Figure I Differential methylation study in ten MDS patients vs 3 healthy individuals from bone marrow samples. (A) Heatmap representing a supervised cluster centred on the median of the methylation levels at the 242I CpG sites between ten MDS patients (A) vs 3 healthy individuals (N). Samples represented as A (Salmon orange) and $\mathrm{N}$ samples (purple). Hypermethylated CPG probes in MDS patients (orange) and hypomethylated probes (blue). (B) Volcano plot representation of methylation for significant $C_{P G}$ sites of genes. Hypomethylated probes are represented in green colour and hypermethylated probes are represented in red. Red lines delimit \pm 0.1 methylation differences between MDS patients vs healthy donors and the dotted line represents a $p$-value threshold of 0.05 . (C) Significantly changed GOs of hypomethylated genes in MDS patients. The $y$ axis shows category and the $x$ axis, -LgP. The larger -LgP indicated a smaller $P$ value.
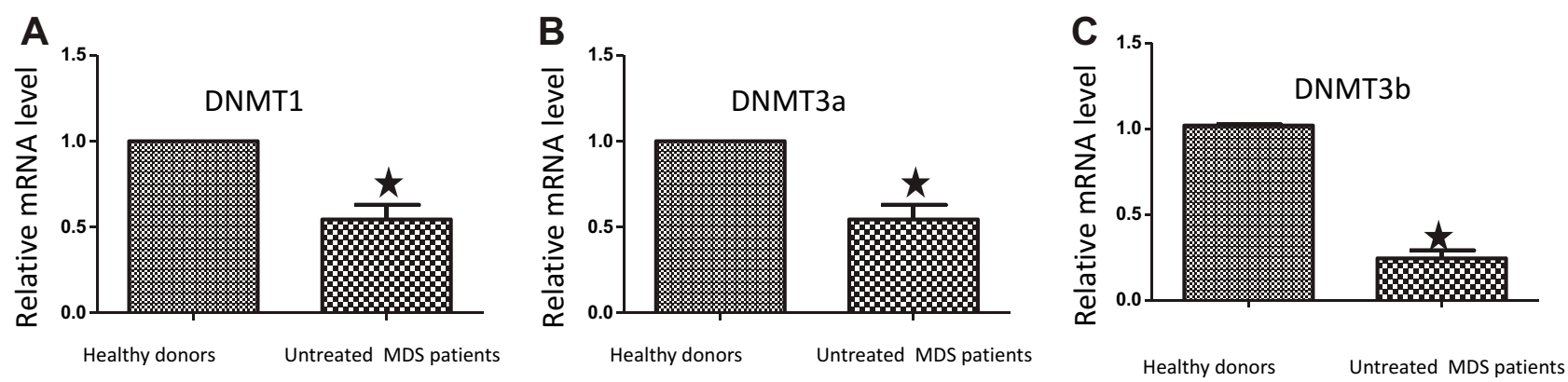

Figure 2 The mRNA expressions for DNMTs in MDS patients were lower than those in controls. Bone marrow cells were extracted from ten untreated MDS patients and 3 healthy donors and then subjected to real-time PCR to measure the mRNA levels of DNMTI (A), DNMT3a (B) and DNMT3b (C). The error bars indicate mean \pm SEM. *, $P<0.05$, compared to those in healthy donors.

\section{$\mathrm{As}_{2} \mathrm{~S}_{2}$ Improved the Hypomethylation in SKM-I Cells}

We conducted an analysis of the changes in the DNA methylation status in SKM-1 cells after treatment with $\mathrm{A}_{\mathrm{S} 2} \mathrm{~S}_{2}$ using an Infinium Human Methylation $850 \mathrm{~K}$ BeadChip. SKM-1 cells were divided into 3 groups and were treated with 0 (control), 1 (low-dose) or $2 \mu \mathrm{mol} / \mathrm{L}$ (high-dose) of $\mathrm{A}_{\mathrm{S} 2} \mathrm{~S}_{2}$ for $48 \mathrm{~h}$.

There were 9 samples that underwent methylation analysis. The control group contained A1, A2 and A3; B1, B2, $\mathrm{B} 3$ and $\mathrm{C} 1, \mathrm{C} 2, \mathrm{C} 3$ represent low-dose group and high-dose group, respectively. The analysis of the mean methylation 

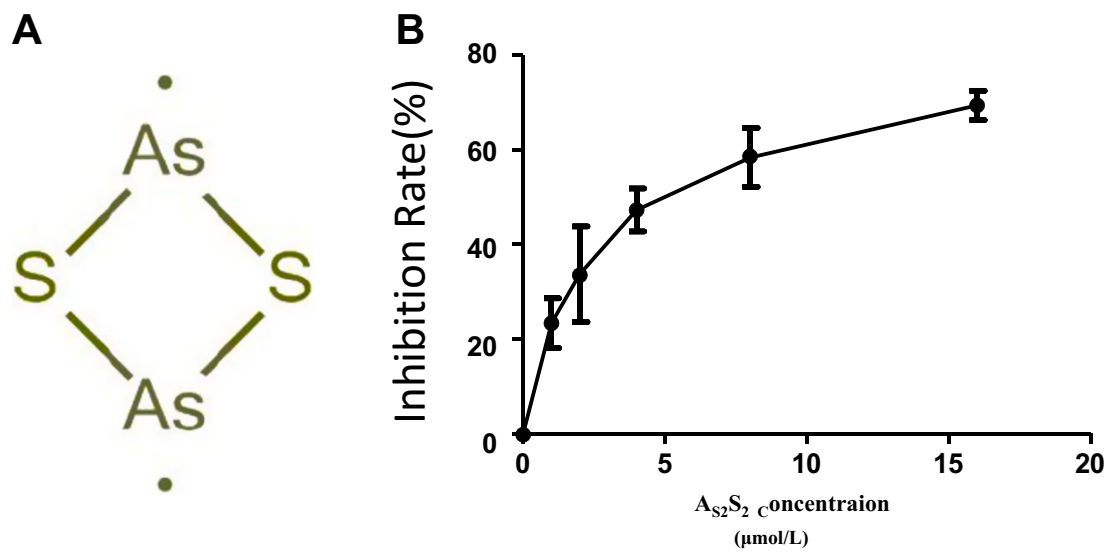

Figure 3 Effects of $\mathrm{As}_{2} \mathrm{~S}_{2}$ on cell proliferation of SKM-I cells. (A) Chemical structure of $\mathrm{As}_{2} \mathrm{~S}_{2}$. (B) Dose-response curve for the proliferation of SKM-I cell line after treatment with $\mathrm{As}_{2} \mathrm{~S}_{2}$ for $48 \mathrm{~h}$. The error bars indicate mean $\pm \mathrm{SEM}$. Results from three independent experiments were shown.

of cytosines showed that the methylation level in the highdose group was higher than that in other groups (Figure 4A). The red represents hypermethylated sites, and the green represents hypomethylated sites in Figure 4B and $\mathrm{C}$. The distribution of differentially methylated sites on the chromosomes between low-dose group and control group revealed that $1 \mu \mathrm{mol} / \mathrm{L} \quad \mathrm{A}_{\mathrm{S}_{2}} \mathrm{~S}_{2}$ treatment had little effect on DNA methylation in SKM-1 cells (Figure 4B). However, methylation status at a large number of sites changed after $2 \mu \mathrm{mol} / \mathrm{L} \quad \mathrm{A}_{\mathrm{S} 2} \mathrm{~S}_{2}$ treatment compared to those in controls (Figure 4C).

Furthermore, as shown in Tables 1 and $\underline{\mathrm{S}} 4$, the methylation of 1718 sites was significantly changed by treatment with $\mathrm{A}_{\mathrm{S} 2} \mathrm{~S}_{2}$ at $2 \mu \mathrm{mol} / \mathrm{L}$ for $48 \mathrm{~h}$, which corresponded to 1032 genes. Among the 1032 genes, 975 genes (94.47\%) were hypermethylated following the treatment compared to that in the controls and part of these hypermethylated genes induced by $\mathrm{A}_{\mathrm{S} 2} \mathrm{~S}_{2}$ at $2 \mu \mathrm{mol} / \mathrm{L}$ were listed in Table S5. In the low-dose group, only 12 sites ( 9 genes) were differentially methylated after $1 \mu \mathrm{mol} / \mathrm{L}-\mathrm{A}_{\mathrm{S} 2} \mathrm{~S}_{2}$ treatment compared to those in control group (Tables 1, $\underline{\mathrm{S} 4}$ ). Table 2 shows the distribution of the differentially methylated sites and the positions of genes in the high-dose group compared to those in control group.

\section{$\mathrm{As}_{2} \mathrm{~S}_{2}$ Decreased the mRNA Expression of the Hypermethylated Genes in SKM-I Cells}

To address the question of whether $\mathrm{A}_{\mathrm{S} 2} \mathrm{~S}_{2}$ treatment changed mRNA expression levels of the hypermethylated genes in high-dose group compared to those in controls, FGF1 and IGF1 were chosen to undergo RT-PCR analysis, based on the results from the Human Methylation $850 \mathrm{~K}$.
Treatment with $2 \mu \mathrm{moL} \quad \mathrm{AS}_{2} \mathrm{~S}_{2}$ for $48 \mathrm{~h}$ resulted in a significant decrease in FGF1 and IGF1 mRNA expression compared to the mRNA expression in control cells, while $1 \mu \mathrm{moL} \mathrm{AS}_{2} \mathrm{~S}_{2}$ treatment for $48 \mathrm{~h}$ did not change the expression compared to that in controls (Figure 5).

\section{$\mathrm{As}_{2} \mathrm{~S}_{2}$ Increased the Expressions of DNMTI, DNMT3a, and DNMT3b in $\mathrm{As}_{2} \mathrm{~S}_{2}$-Treated SKM-I Cells}

We next focused on mRNA and protein expressions of DNMTs following $\mathrm{As}_{2} \mathrm{~S}_{2}$ treatment. SKM-1 cells were treated with $0,1,2$ and $4 \mu \mathrm{mol} / \mathrm{L}$ of $\mathrm{As}_{2} \mathrm{~S}_{2}$ for $48 \mathrm{~h}$. As shown in Figures 6 and 7, compared to controls, 2 and 4 $\mu \mathrm{mol} / \mathrm{L} \quad \mathrm{As}_{2} \mathrm{~S}_{2}$ treatments significantly increased expressions of DNMT1, DNMT3a, and DNMT3b, whereas 1 $\mu \mathrm{mol} / \mathrm{L} \mathrm{As}_{2} \mathrm{~S}_{2}$ treatment had no effect on expressions of DNMTs.

\section{Discussion}

The present work is the first to address the effects of $\mathrm{A}_{\mathrm{S} 2} \mathrm{~S}_{2}$ on DNA methylation in SKM-1 cells, to the best of our knowledge, demonstrating that treatment with $\mathrm{A}_{\mathrm{S}_{2}} \mathrm{~S}_{2}$ could increase the level of DNA methylation by increasing DNMTs expression in MDS cells.

DNA methylation belongs to epigenetics and plays an important role in tumourigenesis through regulating gene expression. Previous many studies have shown that abnormal DNA methylation is a key event in MDS. ${ }^{19}$ Hypomethylating agents targeting hypermethylation are already employed for the treatment of MDS. Besides hypermethylation, abnormal hypomethylation has also been observed in cancer. In fact, early studies showed 

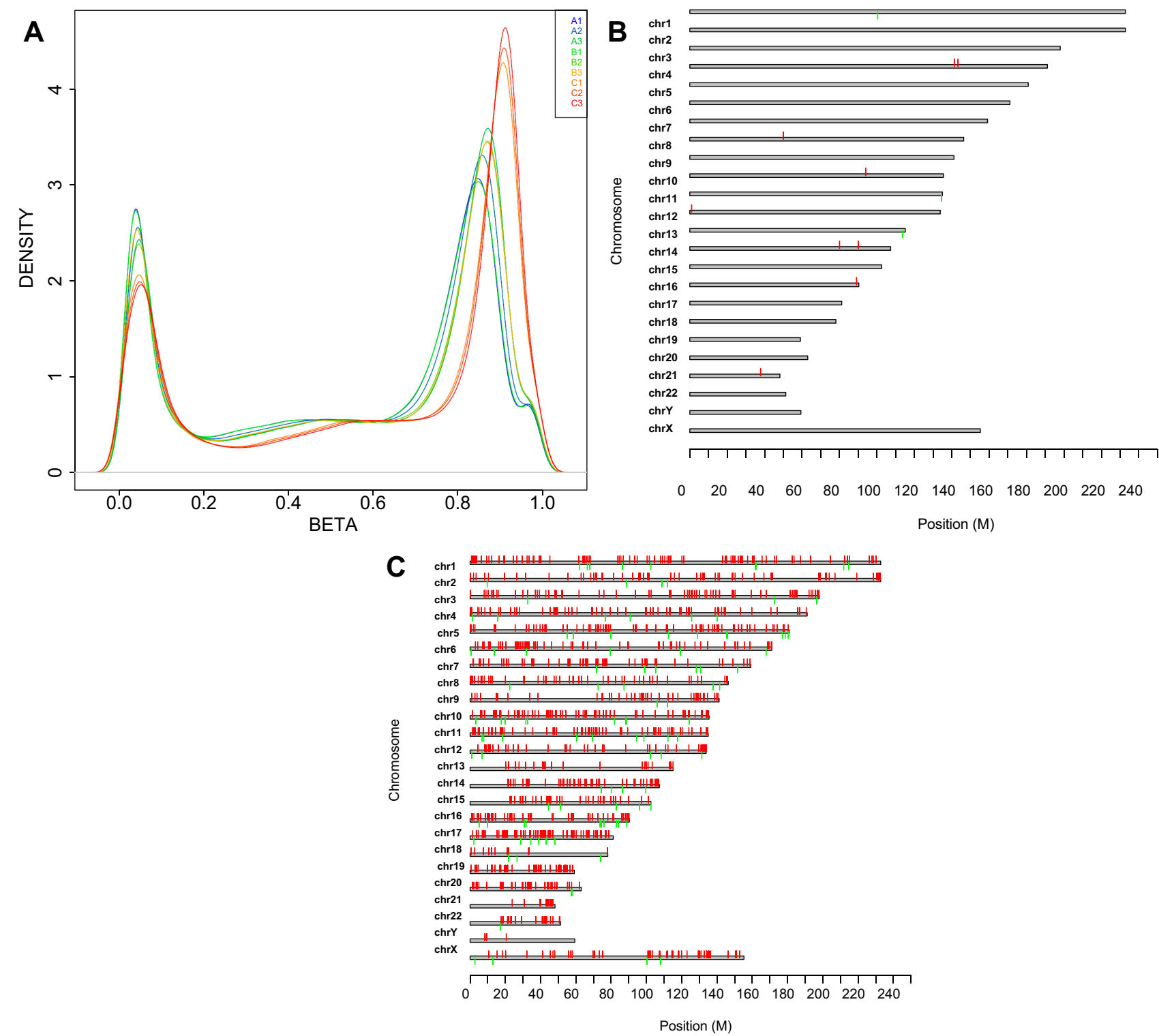

Figure 4 Nine samples in 3 groups were checked by Human Methylation 850K. (A) Mean methylation level of cytosine in 3 groups by Human Methylation $850 \mathrm{~K}$ : Control group contains $\mathrm{Al}, \mathrm{A} 2$ and $\mathrm{A} 3 ; \mathrm{BI}, \mathrm{B} 2, \mathrm{~B} 3$ and $\mathrm{Cl}, \mathrm{C} 2, \mathrm{C} 3$ represents $1 \mu \mathrm{mol} / \mathrm{L}-\mathrm{As}_{2} \mathrm{~S}_{2}$ treatment group and $2 \mu \mathrm{mol} / \mathrm{L}-\mathrm{As}_{2} \mathrm{~S}_{2}$ treatment group, respectively. Distribution of differently methylated sites in chromosomes between $1 \mu \mathrm{mol} / \mathrm{L}-\mathrm{As}_{2} \mathrm{~S}_{2}$ treatment group and control group (B) and $2 \mu \mathrm{mol} / \mathrm{L}-\mathrm{As}_{2} \mathrm{~S}_{2}$ treatment group and control group $(\mathbf{C})$ : the red represents hypermethylated sites; the green represents hypomethylated sites.

that hypomethylation was the dominant change in cancer by measuring the global 5-methylcytosine content. Hypomethylation can lead to chromosomal instability and the transcriptional activation of oncogenes in cancer, including in MDS. ${ }^{10,20-23}$
In our study, we also found that many abnormally hypomethylated genes existed in MDS patients compared to those in healthy donors, which is consistent with previous reports. ${ }^{10} \mathrm{GO}$ analysis showed that these abnormally hypomethylated genes took part in cancer-related

Table I Number of Differently Methylated Sites Among 3 Groups

\begin{tabular}{|l|l|l|l|}
\hline Groups & Differential Methylation Sites_Num & Hypermethylated Sites_Num & Hypomethylated Sites_Num \\
\hline Low vs control & 12 & 9 & 3 \\
High vs control & 1718 & 1625 & 93 \\
High vs low & 1500 & 1387 & 113 \\
\hline
\end{tabular}


Table 2 Distribution of Differently Methylated Sites in the Positions of Genes in High-Dose Comparing with Those in Control Group

\begin{tabular}{|l|l|l|l|}
\hline Region & Sum_Num & Hypomethylated Genes_Num & Hypermethylated Genes_Num \\
\hline Ist Exon & 25 & 0 & 25 \\
3'UTR & 69 & 1 & 68 \\
5'UTR & 118 & 5 & 113 \\
Body & 559 & 32 & 527 \\
TSSI500 & 187 & 14 & 173 \\
Tss200 & 74 & 5 & 69 \\
\hline
\end{tabular}

functions and pathways, such as cell proliferation, the apoptotic process, and the Wnt receptor signalling pathway, which supported the importance of hypomethylation in MDS. To normalize the aberrant hypomethylation in MDS, drugs targeting hypomethylation will be required.

Arsenic disulfide (realgar) has been used therapeutically as part of traditional Chinese medicine for more than 2000 years. ${ }^{24}$ It is of great interest to understand the effects of $\mathrm{As}_{2} \mathrm{~S}_{2}$ on DNA methylation in MDS. In this study, we performed a genome-wide methylation analysis in SKM-1 cells treated with $\mathrm{As}_{2} \mathrm{~S}_{2}$ with an Illumina Human Methylation $850 \mathrm{~K}$ Array. The data showed that treatment with $\mathrm{As}_{2} \mathrm{~S}_{2}$ mainly induced DNA hypermethylation, and the DNA methylation microarray analyses presented here identified hundreds of hypermethylated genes. For example, $\mathrm{As}_{2} \mathrm{~S}_{2}$ treatment induced GLUD1 hypermethylation at $\mathrm{CpG}$ islands. Previous studies have found that GLUD1 is often upregulated in many cancers and the
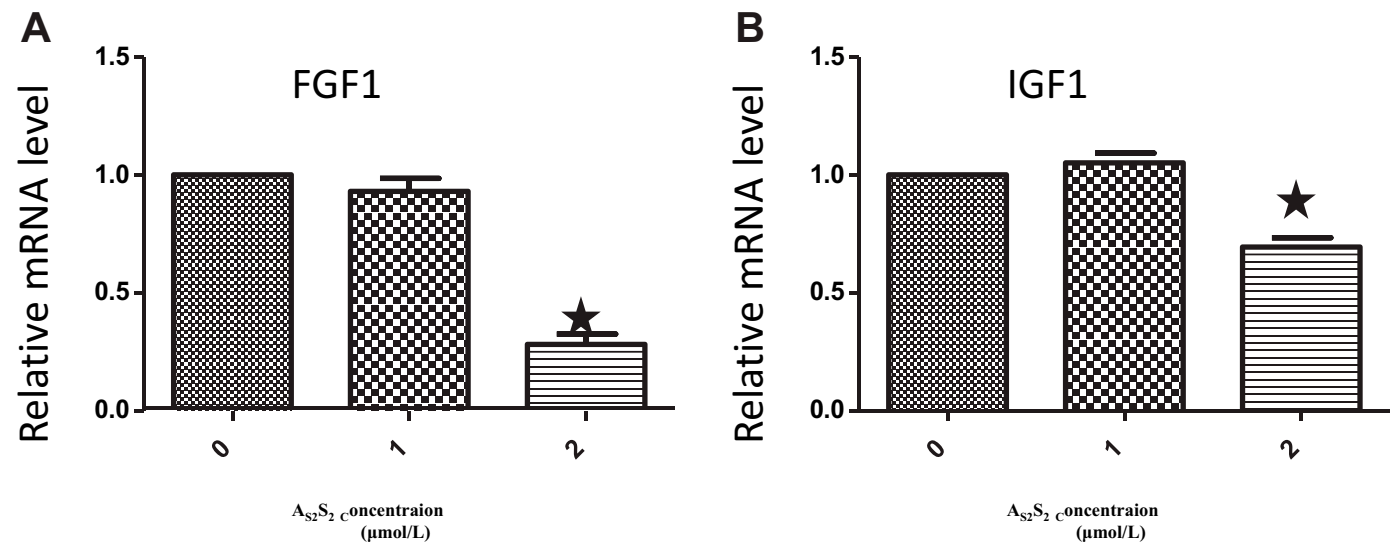

Figure $5 \mathrm{As}_{2} \mathrm{~S}_{2}$ inhibited the mRNA expression of FGFI and IGFI in SKM-I cells. SKM-I cells were treated with $A_{S_{2}} S_{2}(0, I$ and $2 \mu m o l / L)$ for 48 hours and then subjected to real-time PCR to measure the mRNA levels of FGFI (A), and IGFI (B). The error bars indicate mean \pm SEM. Results from three independent experiments were shown. Each bar represents the mean \pm SD of three independent experiments. $* \square P<0.05$, compared with control group.
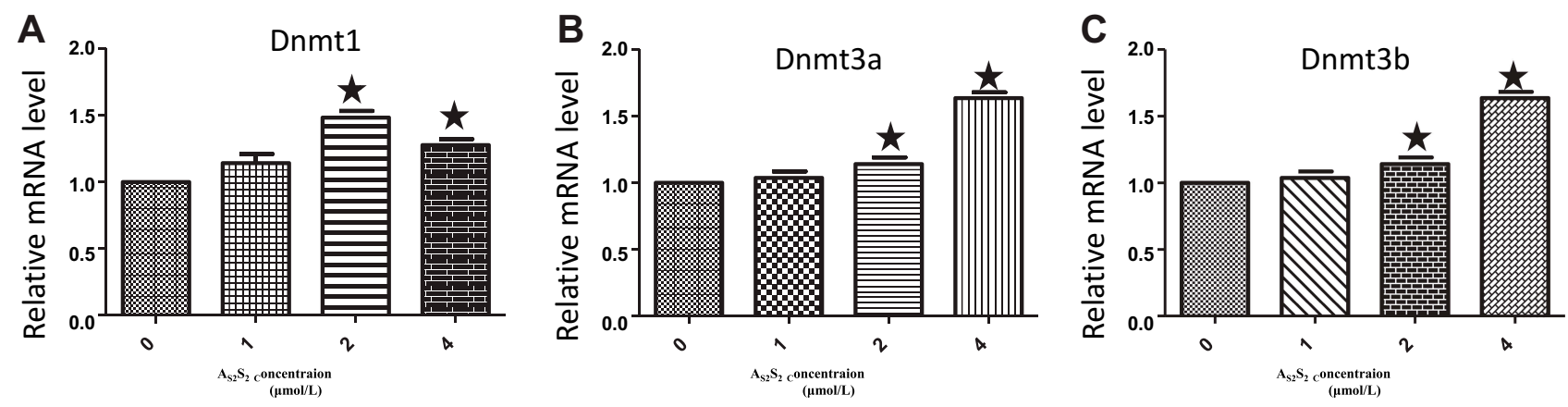

Figure $6 \mathrm{As}_{2} \mathrm{~S}_{2}$ increases the mRNA expression of DNMTs in SKM-I cells. SKM-I cells were treated with As $\mathrm{S}_{2}(0, \mathrm{I}, 2$ and $4 \mu \mathrm{mol} / \mathrm{L})$ for 48 hours, and then real-time PCR was used to check the mRNA levels of DNMTI (A), DNMT3a (B) and DNMT3b (C). Results from three independent experiments were shown. Each bar represents the mean \pm SD of three independent experiments. ${ }^{*}, P<0.05$, compared with control group. 
A
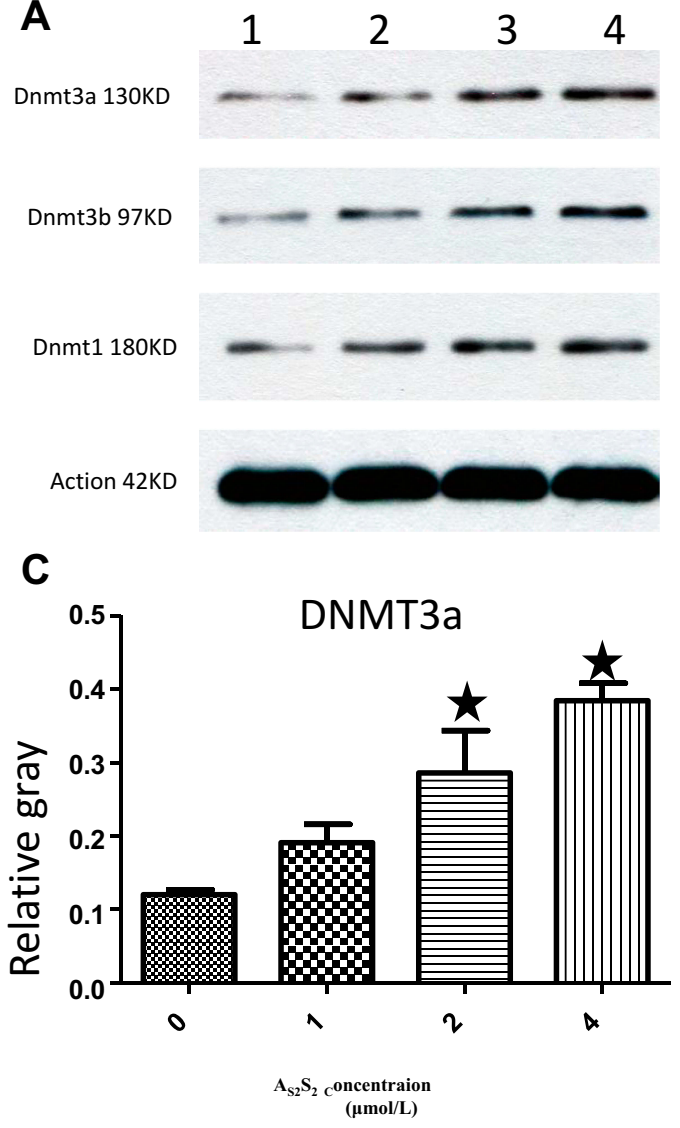

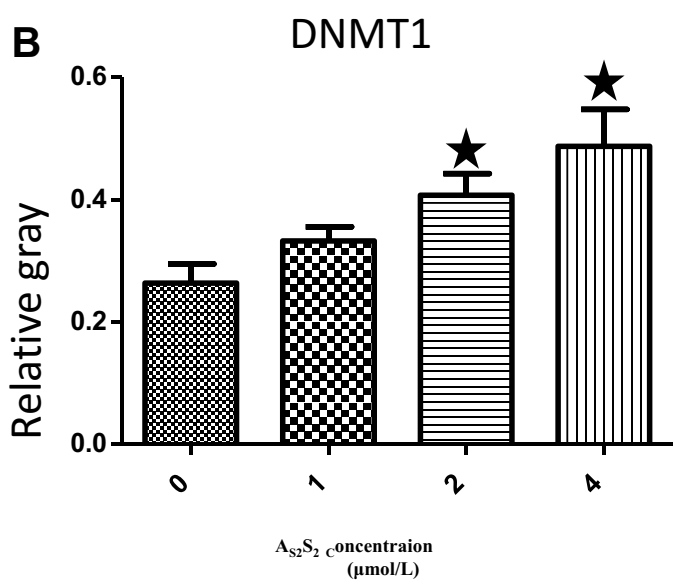

D

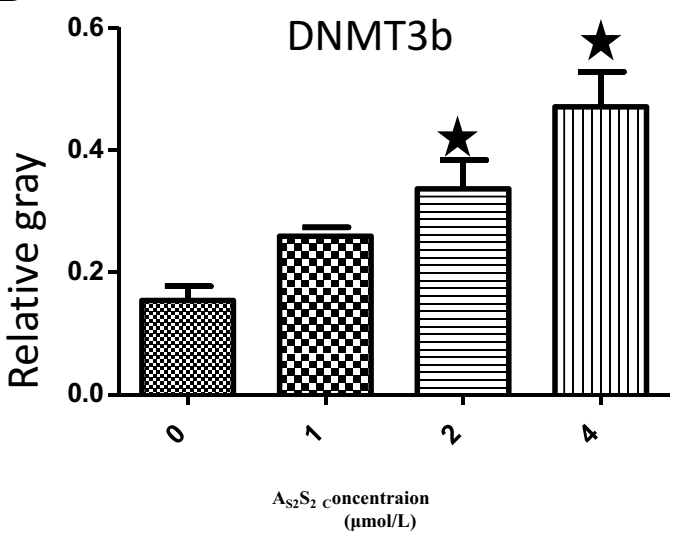

Figure $7 \mathrm{As}_{2} \mathrm{~S}_{2}$ increased the protein expression of DNMTs in SKM-I cells. (A) SKM-I cells were treated with As $\mathrm{S}_{2}(0, \mathrm{I}, 2$ and $4 \mu \mathrm{mol} / \mathrm{L})$ for 48 hours, and Western blotting was used to check protein levels of DNMTI, DNMT3a and DNMT3b. Gray values of DNMTI (B), DNMT3a (C) and DNMT3b (D) were showed. Results were from three independent experiments. Each bar represents the mean \pm SD of three independent experiments. *, $P<0.05$, compared with control group.

inhibition of GLUD1 results in a reduction in cancer cell proliferation and growth. ${ }^{25,26}$ Another gene HSPA5 was hypermethylated after $\mathrm{As}_{2} \mathrm{~S}_{2}$ treatment, which is a member of the molecular chaperone family. ${ }^{27}$ HSPA5 promotes cell survival and has been found to be upregulated in many kinds of cancer cells. ${ }^{28,29}$ Targeting HSPA5 may be a good option for the treatment of cancer. Taken together, these observations suggest that $\mathrm{As}_{2} \mathrm{~S}_{2}$ treatment causes hypermethylation of cancer-related genes, which might be the main mechanism of action of $\mathrm{As}_{2} \mathrm{~S}_{2}$ in the treatment of MDS. Furthermore, this mechanism is different from that of the DNA methylation inhibitors decitabine and azacitidine, which have the ability to demethylate aberrantly hypermethylated genes, causing hypomethylation. ${ }^{30}$

It is well known that DNA methylation is an epigenetic modification that can play an important role in the control of gene expression, and the presence of methylated $\mathrm{CpG}$ islands in promoter regions typically suppresses expression, while hypomethylation leads to over-expression. ${ }^{31}$ Consistent with multiple previous reports, our results showed that the mRNA expression of the hypermethylated genes FGF1 and IGF1R decreased with $\mathrm{As}_{2} \mathrm{~S}_{2}$ treatment compared to those in the controls. FGF1 is a 155 amino acid non-glycosylated polypeptide that functions as a proliferation, differentiation, and survival factor in a wide variety of cell types. ${ }^{32}$ A significant decrease in the expression of the hypermethylated FGF1 gene was observed in our study. FGF1 is a well-known angiogenic growth factor that is essential for tumour growth and may serve as a potential therapeutic target for cancer treatment. ${ }^{33}$ IGF1R, as a driver oncogene, is overexpressed in cancers such as breast, thyroid, prostate, and ovarian cancers, colorectal cancer cells that regulates cancer cell proliferation by modulating apoptotic signalling. ${ }^{34}$ IGF1R promotes cancer spreading and metastasis and is considered an attractive target in the treatment of cancer. ${ }^{35,36}$ In our study, treatment with $\mathrm{As}_{2} \mathrm{~S}_{2}$ at $2 \mu \mathrm{mol} /$ $\mathrm{L}$ induced a significant decrease in the mRNA expression of the hypermethylated gene IGF1R compared to that in the controls. These observations, along with the fact that 
aberrant gene-specific hypomethylation is common in MDS, provide a rationale for the use of $\mathrm{As}_{2} \mathrm{~S}_{2}$ in the treatment of MDS.

DNA methylation, or the covalent addition of a methyl group from $S$-adenosylmethionine (SAM) to cytosine by DNMTs, is an essential epigenetic modification of the genome in mammalian cells. ${ }^{37,38}$ In our study, the mRNA expression of DNMTs significantly decreased in MDS patients. However, $\mathrm{As}_{2} \mathrm{~S}_{2}$ treatment significantly increased the expression of DNMTs at the mRNA and protein levels in SKM-1 cells. The results show that $\mathrm{As}_{2} \mathrm{~S}_{2}$ upregulated the level of DNA methylation by increasing DNA methyltransferases expression in SKM-1 cell line, and $\mathrm{As}_{2} \mathrm{~S}_{2}$ may be an innovative hypermethylation agent.

\section{Conclusion}

In summary, our study suggests that many hypomethylated genes existed in MDS patients due to the low expression of DNMTs. $\mathrm{As}_{2} \mathrm{~S}_{2}$ promotes DNA methylation in SKM-1 cells by increasing the expression of DNMTs. Furthermore, $\mathrm{As}_{2} \mathrm{~S}_{2}$ treatment can lead to the hypermethylation of cancer-related genes, which may be the main mechanism of action in the treatment of MDS. Whether the in vitro effects of $\mathrm{As}_{2} \mathrm{~S}_{2}$ translate into better response and survival rates in patients with MDS needs to be examined in clinical trials in the future.

\section{Acknowledgments}

The authors thank China Academy of Chinese Medicine Scientific Foundation (ZZ13-YQ-010), Beijing Natural Scientific Foundation (7174344) and the National Natural Scientific Foundation of China $(81603490,81774140)$ for funding. Professor Ma gave us much help in this study.

\section{Author Contributions}

All authors contributed to data analysis, drafting or revising the article, gave final approval of the version to be published, and agree to be accountable for all aspects of the work.

\section{Disclosure}

The authors declare that they have no conflicts of interest.

\section{References}

1. Pan YB, Liu GH, Zhou FL, Su BJ, Li YR. DNA methylation profiles in cancer diagnosis and therapeutics. Clin Exp Med. 2018;18(1):1-14. doi:10.1007/s10238-017-0467-0
2. Nebbioso A, Tambaro FP, Dell'Aversana C, Altucci L. Cancer epigenetics: moving forward. PLoS Genet. 2018;14(6):e1007362. doi:10.1371/journal.pgen.1007362

3. Qian J, Zhu Z-H, Lin J, et al. Hypomethylation of PRAME promoter is associated with poor prognosis in myelodysplastic syndrome. $\mathrm{Br}$ J Haematol. 2011;154(1):153-155. doi:10.1111/j.1365-2141.2011.08 585.x

4. Bollati V, Baccarelli A, Hou L, et al. Changes in DNA methylation patterns in subjects exposed to low-dose benzene. Cancer Res. 2007;67(3):876-880. doi:10.1158/0008-5472.CAN-06-2995

5. Chen Q, Lin J, Yao DM, et al. Aberrant hypomethylation of DDX43 promoter in myelodysplastic syndrome. Br J Haematol. 2012;158 (2):283-296. doi:10.1111/j.1365-2141.2012.09138.x

6. Nakayama M, Wada M, Harada T, et al. Hypomethylation status of $\mathrm{CpG}$ sites at the promoter region and overexpression of the human MDR1 gene in acute myeloid leukemias. Blood. 1998;92 (11):4296-4307. doi:10.1182/blood.V92.11.4296

7. Yamashita K, Hosoda K, Nishizawa N, Katoh H, Watanabe M. Epigenetic biomarkers of promoter DNA methylation in the new era of cancer treatment. Cancer Sci. 2018;109(12):3695-3706. doi: $10.1111 /$ cas. 13812

8. Flotho C, Sommer S, Lübbert M. DNA-hypomethylating agents as epigenetic therapy before and after allogeneic hematopoietic stem cell transplantation in myelodysplastic syndromes and juvenile myelomonocytic leukemia. Semin Cancer Biol. 2018;51:68-79. doi:10.1016/j.semcancer.2017.10.011

9. Montalban-Bravo G, Garcia-Manero G. Myelodysplastic syndromes: 2018 update on diagnosis, risk-stratification and management. $\mathrm{Am}$ J Hematol. 2018;93(1):129-147. doi:10.1002/ajh.24930

10. Jelinek J, Liang S, Neumann F, et al. Cancer drivers affected by aberrant DNA methylation in MDS and AML. Blood. 2011;118 (21):1716. doi:10.1182/blood.V118.21.1716.1716

11. Kortsaris AC, Matsouka PT. Aberrant methylation of c-myc and c-fos protooncogenes and p53 tumor suppressor gene in myelodysplastic syndromes and acute non-lymphocytic leukemia. J BUON. 2003;8 (4):341-350.

12. Lin J, Qian J, Yao DM, et al. Aberrant hypomethylation of SALL4 gene in patients with myelodysplastic syndrome. Leuk Res. 2013;37 (1):71-75. doi:10.1016/j.leukres.2012.10.014

13. Wu DH, Yao DM, Yang L, et al. Hypomethylation of let-7a-3 is associated with poor prognosis in myelodysplastic syndrome. Leuk Lymphoma. 2017;58(1):96-103. doi:10.1080/10428194.2016.1187 273

14. Vardiman JW, Thiele J, Arber DA, et al. The 2008 revision of the World Health Organization (WHO) classification of myeloid neoplasms and acute leukemia: rationale and important changes. Blood. 2009;114:937-951. doi:10.1182/blood-2009-03-209262

15. Nakagawa T, Matozaki S. The SKM-1 leukemic cell line established from a patient with progression to myelomonocytic leukemia in myelodysplastic syndrome (MDS)-contribution to better understanding of MDS. Leuk Lymphoma. 1995;17(3-4):335-339. doi:10.3109/ 10428199509056841

16. Moran S, Arribas C, Esteller M. Validation of a DNA methylation microarray for $850,000 \mathrm{CpG}$ sites of the human genome enriched in enhancer sequences. Epigenomics. 2016;8(3):389-399. doi:10.2217/ epi. 15.114

17. Berardini TZ. The gene ontology in 2010: extensions and refinements. Nucleic Acids Res. 2009;38:331-335.

18. Ashburner M, Ball CA, Blake JA, et al. Gene ontology: tool for the unification of biology. Nat Genet. 2000;25(1):25-29. doi:10.1038/75556

19. Issa JP. The myelodysplastic syndrome as a prototypical epigenetic disease. Blood. 2013;121(19):3811-3817. doi:10.1182/blood-201302-451757

20. Eden A, Gaudet F, Waghmare A, Jaenisch R. Chromosomal instability and tumors promoted by DNA hypomethylation. Science. 2003;300(5618):455. doi:10.1126/science. 1083557 
21. Pogribny IP, Beland FA. DNA hypomethylation in the origin and pathogenesis of human diseases. Cell Mol Life Sci. 2009;66 (14):2249-2261. doi:10.1007/s00018-009-0015-5

22. Wu H, Chen Y, Liang J, et al. Hypomethylation-linked activation of PAX2 mediates tamoxifen-stimulated endometrial carcinogenesis. Nature. 2005;438(7070):981-987. doi:10.1038/nature04225

23. Van Tongelen A, Loriot A, De Smet C. Oncogenic roles of DNA hypomethylation through the activation of cancer-germline genes. Cancer Lett. 2017;396:130-137. doi:10.1016/j.canlet.2017. 03.029

24. Emadi A, Gore SD. Arsenic trioxide - an old drug rediscovered. Blood Rev. 2010;24(4-5):191-199. doi:10.1016/j.blre.2010.04. 001

25. Plaitakis A, Kalef-Ezra E, Kotzamani D, Zaganas I, Spanaki C. The glutamate dehydrogenase pathway and its roles in cell and tissue biology in health and disease. Biology. 2017;6(1):11.

26. Jin L, Li D, Alesi GN, et al. Glutamate dehydrogenase 1 signals through antioxidant glutathione peroxidase 1 to regulate redox homeostasis and tumor growth. Cancer Cell. 2015;27(2):257-270. doi:10.1016/j.ccell.2014.12.006

27. Lee AS. Glucose-regulated proteins in cancer: molecular mechanisms and therapeutic potential. Nat Rev Cancer. 2014;14:263-276. doi:10.1038/nrc3701

28. Hetz C. The unfolded protein response: controlling cell fate decisions under ER stress and beyond. Nat Rev Mol Cell Biol. 2012;13 (2):89-102. doi:10.1038/nrm3270

29. Arap MA, Lahdenranta J, Mintz PJ, et al. Cell surface expression of the stress response chaperone GRP78 enables tumor targeting by circulating ligands. Cancer Cell. 2004;6(3):275-284. doi:10.1016/j. ccr.2004.08.018
30. Heuser M, Yun H, Thol F. Epigenetics in myelodysplastic syndromes. Semin Cancer Biol. 2018;51:170-179. doi:10.1016/j.semcancer.20 17.07.009

31. Baer C, Claus R, Frenzel LP, et al. Extensive promoter DNA hypermethylation and hypomethylation is associated with aberrant microRNA expression in chronic lymphocytic leukemia. Cancer Res. 2012;72(15):3775-3785. doi:10.1158/0008-5472.CAN-12-0803

32. Raju R, Palapetta SM, Sandhya VK, et al. A network map of FGF-1/ FGFR signaling system. J Signal Transduct. 2014;2014:962962. doi: $10.1155 / 2014 / 962962$

33. Li J, Wei Z, Li H, et al. Clinicopathological significance of fibroblast growth factor 1 in non-small cell lung cancer. Hum Pathol. 2015;46:1821-1828. doi:10.1016/j.humpath.2015.07.022

34. Wang X, Zhu Q, Lin Y, et al. Crosstalk between TEMs and endothelial cells modulates angiogenesis and metastasis via IGF1-IGF1R signalling in epithelial ovarian cancer. Br J Cancer. 2017;117 (9):1371-1382. doi:10.1038/bjc.2017.297

35. Pollak M. The insulin receptor/insulin-like growth factor receptor family as a therapeutic target in oncology. Clin Cancer Res. 2012;18(1):40-50. doi:10.1158/1078-0432.CCR-11-0998

36. Zorea J, Prasad M, Cohen L, et al. IGF1R upregulation confers resistance to isoform-specific inhibitors of PI3K in PIK3CA-driven ovarian cancer. Cell Death Dis. 2018;9:944. doi:10.1038/s41419-0181025-8

37. Klein CB, Costa M. DNA methylation and gene expression: introduction and overview. Mutat Res. 1997;386(2):103-105. doi:10.1016/ S1383-5742(96)00046-4

38. Robertson KD, Jones PA. DNA methylation: past, present and future directions. Carcinogenesis. 2000;21:461-467. doi:10.1093/carcin/ 21.3.461
Drug Design, Development and Therapy

\section{Publish your work in this journal}

Drug Design, Development and Therapy is an international, peerreviewed open-access journal that spans the spectrum of drug design and development through to clinical applications. Clinical outcomes, patient safety, and programs for the development and effective, safe, and sustained use of medicines are a feature of the journal, which has also

\section{Dovepress}

been accepted for indexing on PubMed Central. The manuscrip management system is completely online and includes a very quick and fair peer-review system, which is all easy to use. Visit http://www. dovepress.com/testimonials.php to read real quotes from published authors. 